\title{
(bukan) Batik Papua
}

\author{
Albertus Vembrianto', M. Zamzam Fauzanafi² \\ ${ }^{1}$ Fotografer Independen \\ 2 Dosen Antropologi UGM \\ Emai: vembriwaluyas@gmail.com; muhammad.zamzam.f@ugm.ac.id
}

Batik telah diklaim sebagai bagian dari 'identitas bangsa' Indonesia. Batik ditetapkan sebagai sebagai warisan kemanusiaan untuk budaya lisan dan non-benda oleh United Nations Educational, Scientific and Cultural Organization (UNESCO) sejak 2 Oktober 2009 (lih. UNESCO, n.d.). Semenjak itu tanggal 2 Oktober ditetapkan sebagai Hari Batik Nasional. Aturan dan himbauan pemakaian batik baik sebagai seragam kerja, sekolah, atau pemakaian sehari-hari mulai digalakan secara nasional. Termasuk di Papua. Orang papua mulai mengenakan 'batik papua' dalam berbagai kesempatan, terutama dikenakan dalam lingkup formal pekerjaan, sekolah, acara keagamaan, dan pesta. Hal ini bisa dilihat sebagai pengaturan cara berpakaian yang intinya adalah pengaturan tubuh (Jeacle 2012, 84). Proyek pengaturan tubuh yang bernama batik ini kini bukan lagi diperuntukan untuk para elit, tetapi juga bagi massa rakyat. Dengan demikian, mendandani dan membentuk tubuh melalui pakaian adalah bagian penting dari penemuan atau pembentukan objek dan subjek pengetahuan baru. Pakaian bukan hanya untuk melindungi tubuh, tetapi juga sinyal untuk identitas diri. Fenomena 'Batik Papua' menunjukkan ekspresi paling tampak dari bagaimana pakaian berkelindan dengan projek pembentukan diri (project of the self) (Jeacle 2012, 87).

Berikut adalah rangkaian foto dan cerita yang menggambarkan projek pembentukan identitas diri tersebut.

"Mas bisa foto sa kah?", tanya Yohanis. "Bisa to!", jawab saya. Kemudian Yohanis menuju tempat penyimpanan baju, berupa tas cangklong ukuran besar terbuat dari bahan mirip terpal. Tas begitu kebanyakan dipunyai orang-orang asli Papua yang tinggal di kampung, biasa dipakai saat bepergian. Yohanis mengganti kaos yang semula dipakai, dengan kemeja batik. Ia juga mengenakan kacamata hitam untuk berpose.

Saat itu saya sedang berkunjung ke pemukiman di kawasan Papua Selatan, tepatnya perbatasan Kabupaten Merauke dan Boven Digul, untuk membuat reportase visual terkait dampak perusahaan kelapa sawit yang membongkar hutan alam dalam skala raksasa, di tanah ulayat milik orangorang asli Papua.

Beberapa orang memiliki kemeja batik khas Papua karena keanggotaan pada organisasi atau institusi. Seperti Mama Yakomina, kemeja batiknya diperoleh dari organisasi keperempuanan di gereja dimana ia menjadi jemaat. Sementara Theo, kemeja batik diperoleh karena jabatannya 
sebagai pengurus koperasi yang dibuat oleh perusahaan kelapa sawit. Theo sebagai salah satu pengurus marga, dipilih menjadi pengurus koperasi.

Batik motif khas Papua didominasi motif tumbuhan, flora, dan fauna endemik Papua atau peralatan sehari-hari dan budaya di Papua, seperti rumah honai, tifa, panah, tombak. Warna batik khas Papua didominasi warna lebih menyala dibanding motif batik yang biasa ditemui di Jawa.
Salah satu momen penting ketika orang Papua mengenakan batik adalah ritual keagamaan. Dalam hal ini, batik sebagai pakaian, dalam pengertian 'himpunan (assemblage) modifikasi atau suplemen tubuh' (Eicher dan Higgins 1992), secara strategis berfungsi membentuk identitas nasional yang berkelindan dengan moral keagamaan yang bekerja untuk mengubah 'dosa' (ketelanjangan) menjadi 'keberadaban' (Comaroff dan Comaroff 1997).

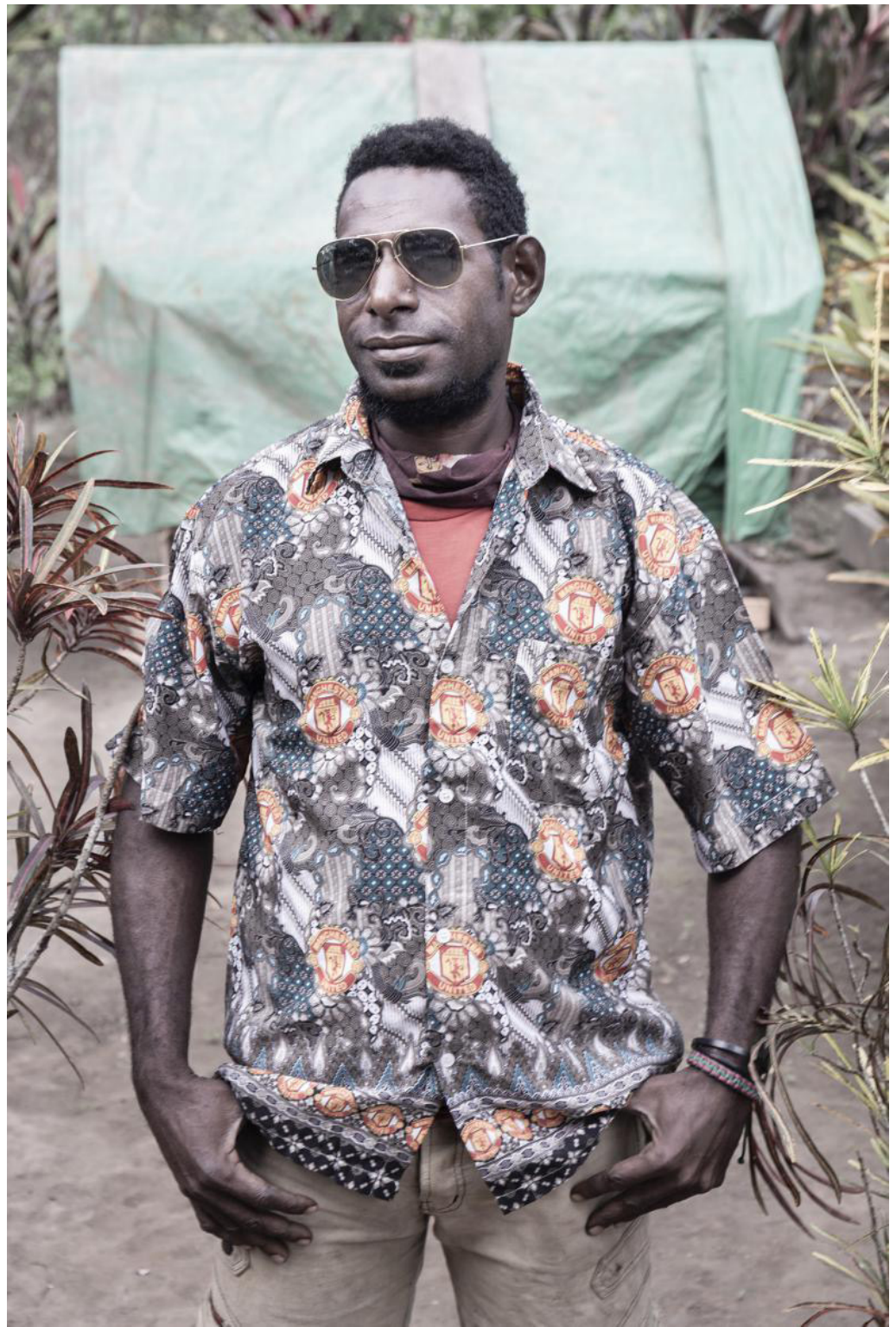

Yohanis, 23, warga asli Papua berpose dengan kemeja batik bermotif lambang kesebelasan sepak bola ternama. Yohanis tinggal di Muting, kampung di ujung utara Kabupaten Merauke yang berbatasan dengan Kabupaten Boven Digul. Perlu sekitar 4 jam perjalanan darat dari pusat kota Merauke. Dulu saat jalan belum diaspal, waktu tempuh Muting ke Merauke bisa 1-3 hari, sesuai kondisi jalan dengan menggunakan mobil berkemampuan offroad. (Foto: Agustus 2019, Albertus Vembrianto) 


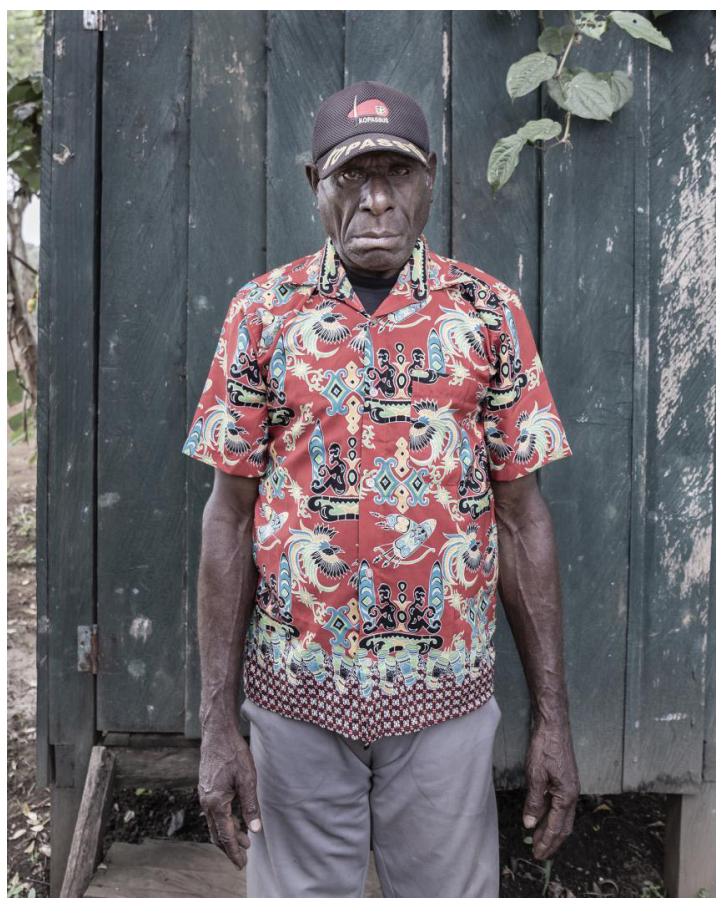

Theo, 61, memakai baju batik seragam pengurus koperasi di kampungnya di Kabupaten Boven Digul. Theo menjadi pengurus koperasi yang dibuat oleh perusahaan kelapa sawit yang beroperasi di tanah adat milik klan Theo. (Foto: Agustus 2019, Albertus Vembrianto)
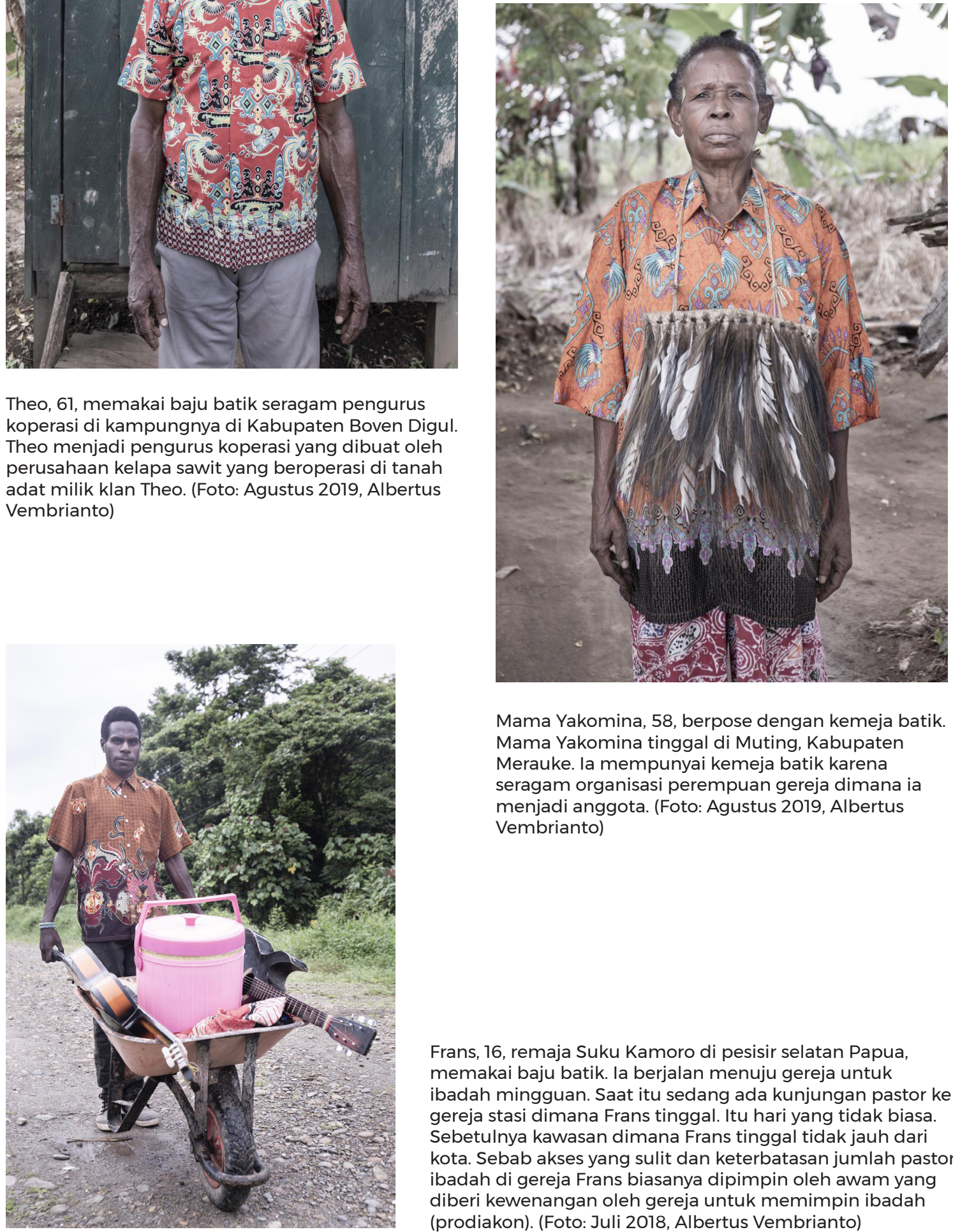

Mama Yakomina, 58, berpose dengan kemeja batik. Mama Yakomina tinggal di Muting, Kabupaten Merauke. la mempunyai kemeja batik karena seragam organisasi perempuan gereja dimana ia menjadi anggota. (Foto: Agustus 2019, Albertus Vembrianto)

Frans, 16, remaja Suku Kamoro di pesisir selatan Papua, memakai baju batik. la berjalan menuju gereja untuk ibadah mingguan. Saat itu sedang ada kunjungan pastor ke gereja stasi dimana Frans tinggal. Itu hari yang tidak biasa. Sebetulnya kawasan dimana Frans tinggal tidak jauh dari kota. Sebab akses yang sulit dan keterbatasan jumlah pastor ibadah di gereja Frans biasanya dipimpin oleh awam yang diberi kewenangan oleh gereja untuk memimpin ibadah (prodiakon). (Foto: Juli 2018, Albertus Vembrianto) 


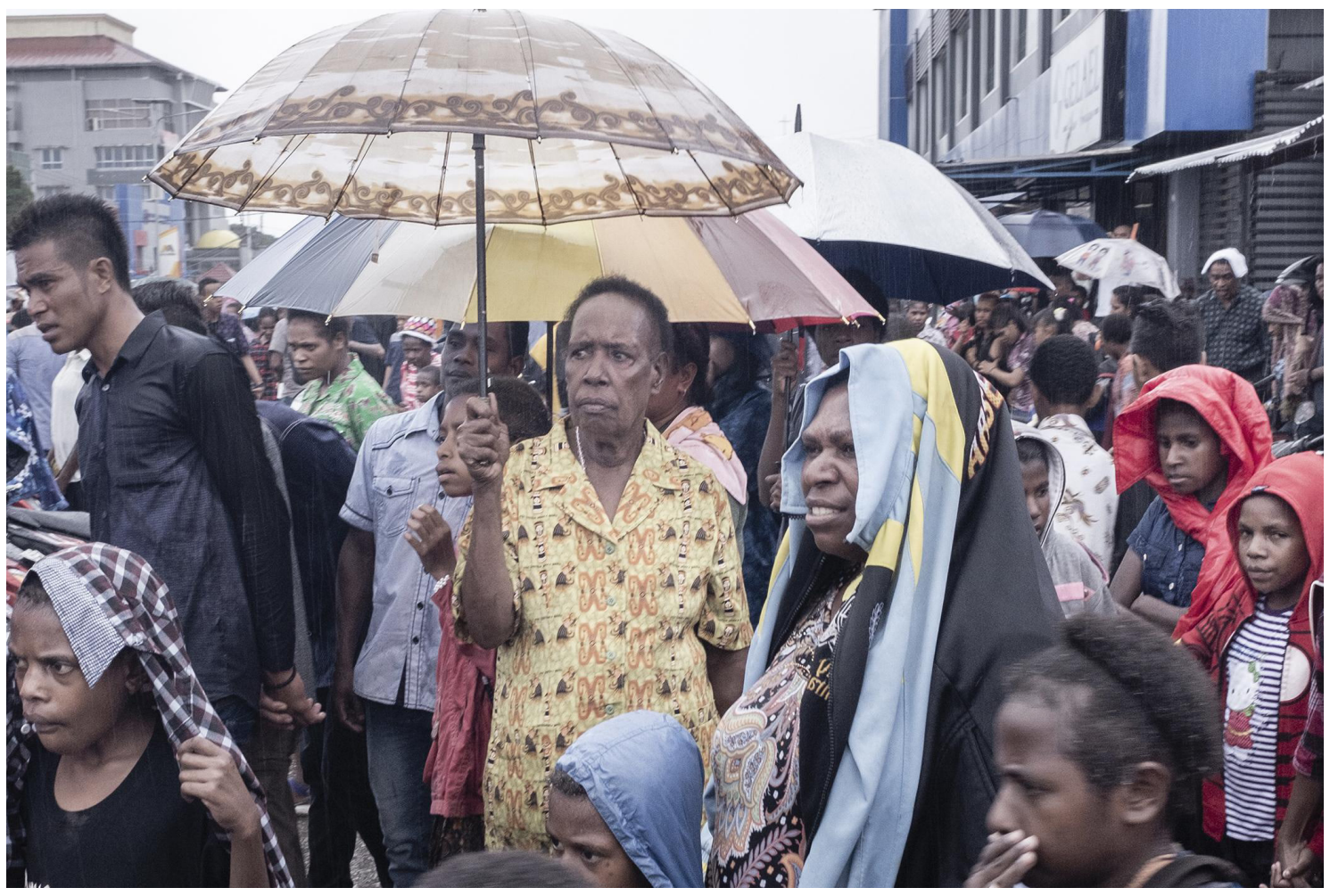

Seorang perempuan asli Papua memakai batik dengan motif Papua dalam prosesi jalan salib, menjelang Paskah di Gereja Katedral Timika, Papua. (Foto: April 2017, Albertus Vembrianto)

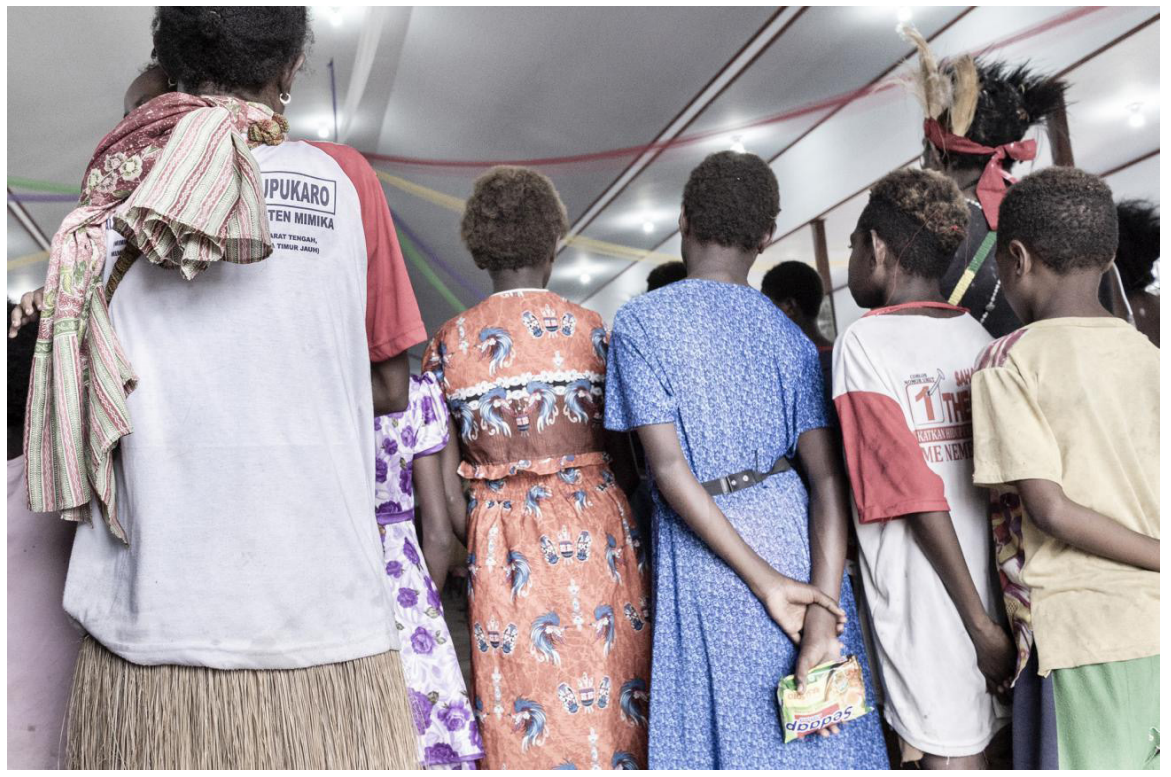

Sejumlah remaja asli Papua berbusana batik mengikuti ibadah pemberkatan gereja di Miyoko, sebuah kampung asli orang Papua pesisir di Kabupaten Mimika. Akses jalan darat kampung Miyoko belum terhubung dengan kawasan kota. Perlu menggunakan perahu untuk sampai di Miyoko. (Foto: Maret 2019, Albertus Vembrianto) 
Kecenderungan memakai baju batik dengan motif khas Papua sebagai seragam organisasi atau institusi, saya temui di beberapa tempat di Papua, baik di kawasan pegunungan dan pesisir. Sejumlah sekolah yang dikelola yayasan berbasis keagamaan, juga memberlakukan seragam dengan motif batik. Begitu juga dengan institusi pemerintah. Selain seragam Korpri, dinasdinas pemerintah daerah di Papua biasanya juga mempunyai seragam batik motif khas Papua, entah level satuan kerja atau wilayah administratif.
Memakai kemeja di Papua, berarti juga membedakan diri dari yang tidak memakai kemeja. Hanya orang-orang tertentu saja yang memakai kemeja. Orang-orang kampung yang tidak cukup berpendidikan dan tidak mempunyai jabatan atau peran tertentu dalam organisasi atau institusi, biasanya tidak memakai kemeja. Kalangan itu biasanya disebut dengan masyarakat. Berkemeja bisa berarti sebuah posisi yang menegaskan, bahwa ia bukan masyarakat yang itu, tapi orang yang mempunyai jabatan.

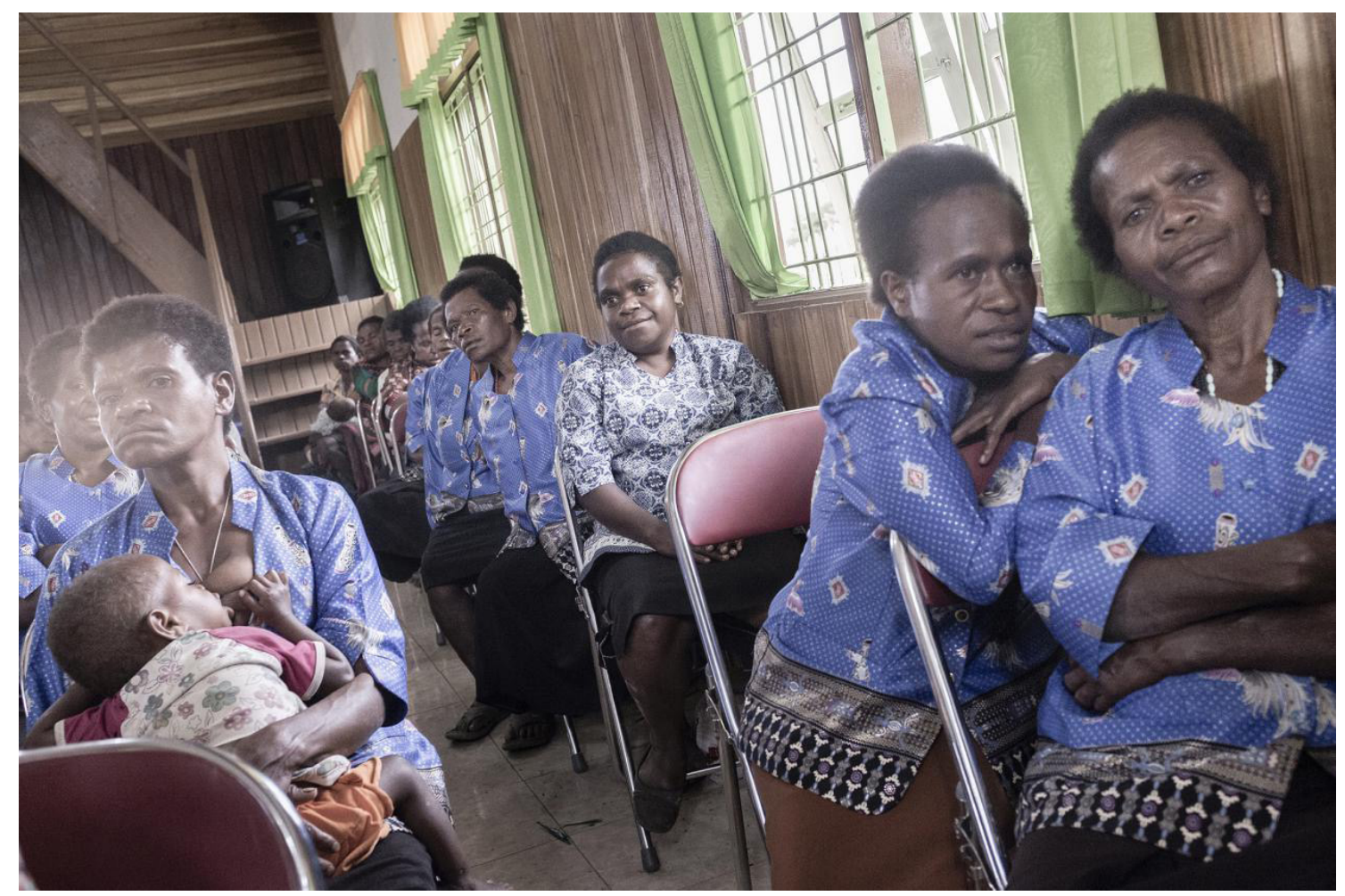

Sejumlah perempuan mengenakan kemeja batik seragam, yang tergabung dalam organisasi Wanita Katolik (WK), mengikuti pertemuan di aula Gereja Paroki Enarotali, Paniai, Papua. (Foto: Agustus 2015, Albertus Vembrianto) 


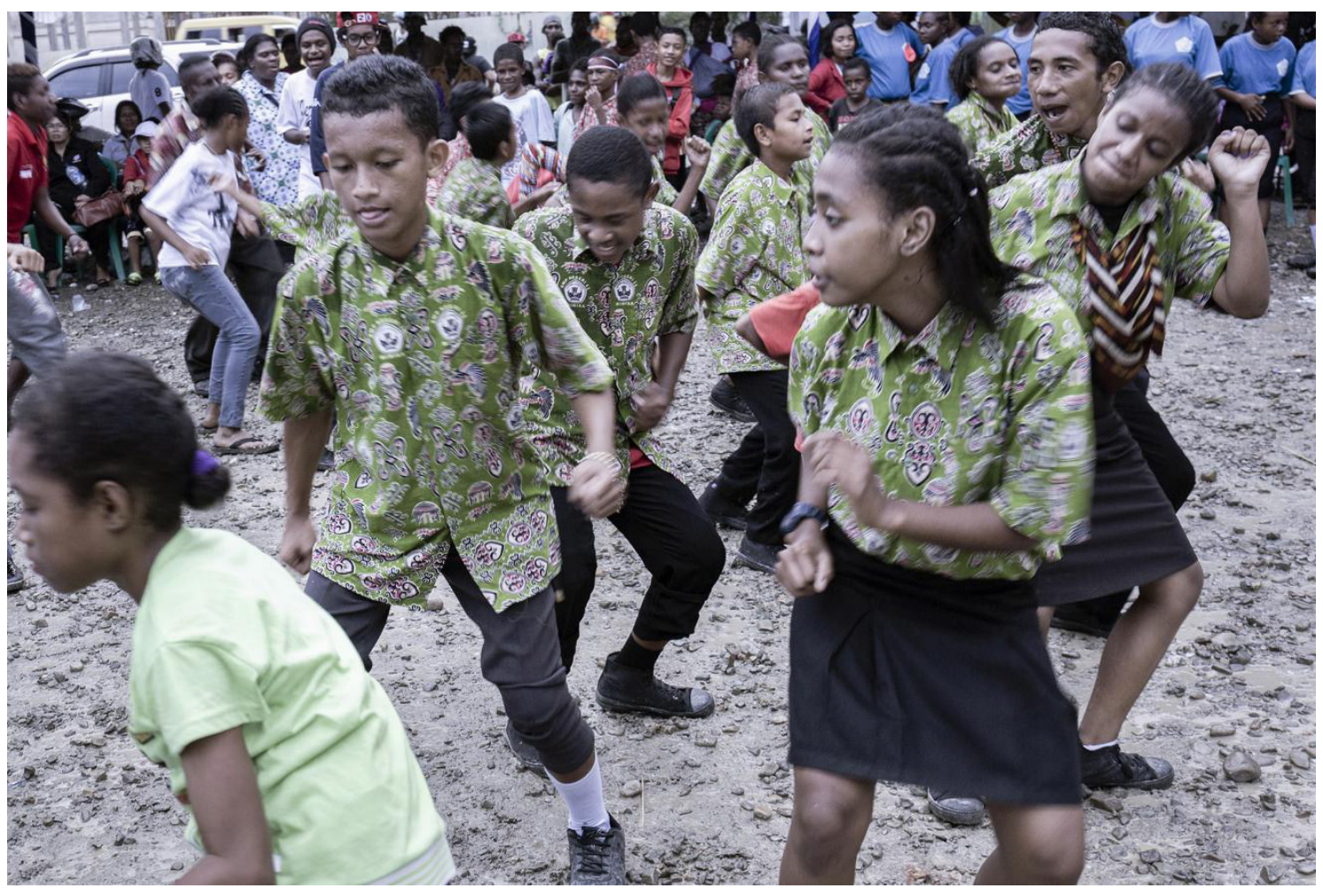

Sejumlah siswa sekolah menengah pertama menari Seka, tarian khas lokal di pesisir selatan Papua dengan menggunakan seragam batik sekolah (Foto: September 2015, Albertus Vembrianto).

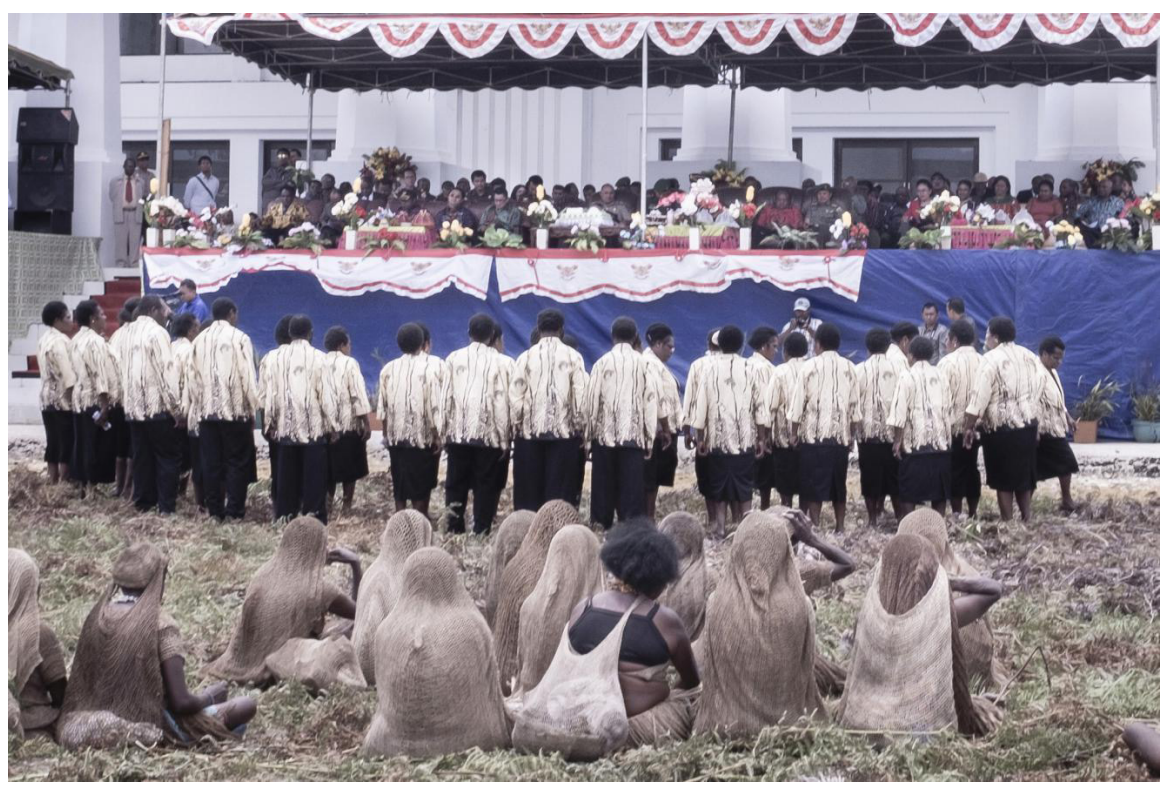

Kelompok paduan suara berbasis Satuan Kerja Perangkat Daerah (SKPD)

berseragam batik dalam acara peringatan hari ulang tahun Kabupaten Paniai di Enarotali (Foto: Oktober 2015, Albertus Vembrianto). 
Saat peringatan hari batik, 2 Oktober, biasanya semua pekerja di kantor-kantor dinas pemerintah akan mengenakan baju dengan motif batik khas Papua, seragam resmi atau bukan seragam.

Kecenderungan mengharuskan batik motif khas Papua menjadi seragam resmi di kalangan dinas pemerintah Papua adalah upaya serius. Temuan kasus korupsi pengadaan seragam batik di lingkungan Pemerintah Kota Jayapura, senilai Rp 1,7 miliar tahun 2012, menunjukkan bahwa urusan seragam batik memang dialokasikan dalam anggaran belanja pemerintah (Pademme, 2014).

Selain sebagai seragam, baju dengan motif khas Papua, juga biasa dipakai untuk busana pernikahan. Seperti di tempat lain di luar Papua, busana seragam pada pesta pernikahan untuk menunjukkan bahwa pemakai busana adalah bagian dari pasangan yang menikah.

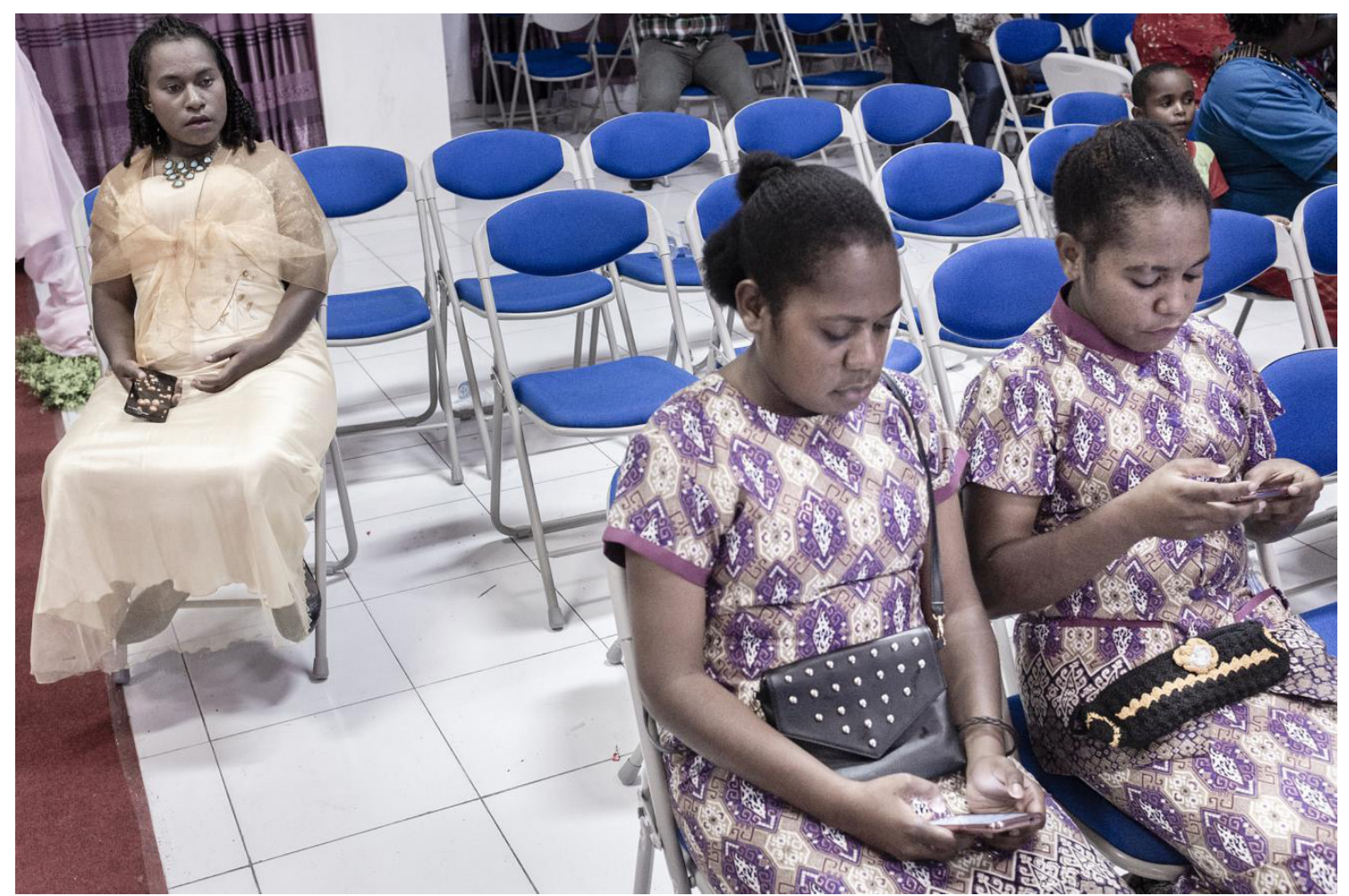

Sejumlah remaja mengenakan batik seragam keluarga mempelai dalam acara pernikahan di Kabupaten Jayapura, Papua. (Foto: Juli 2016, Albertus Vembrianto) 


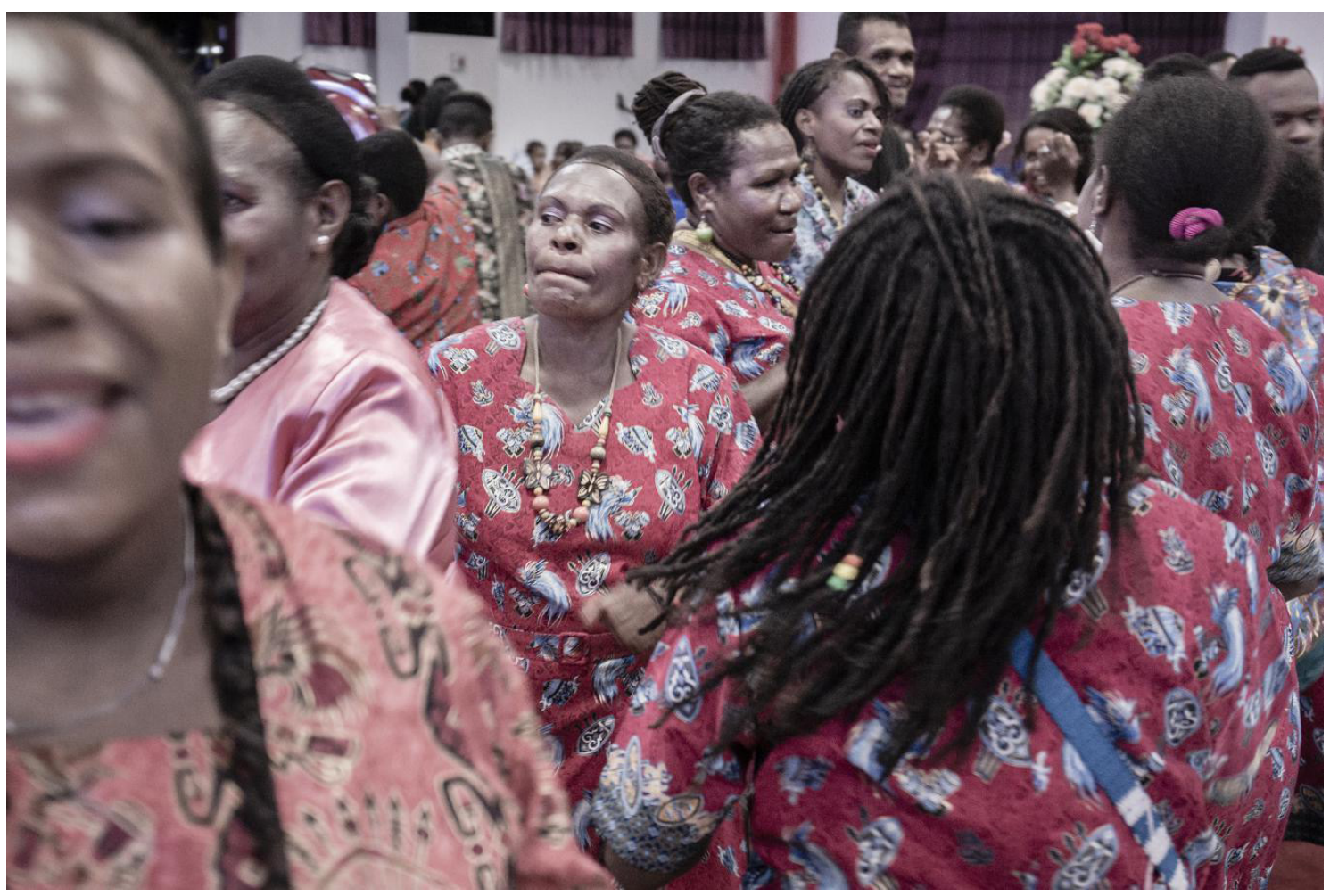

Sejumlah perempuan menari dalam pesta pernikahan di Jayapura, Papua, dengan busana batik seragam keluarga mempelai. (Foto: Juli 2016, Albertus Vembrianto)

Semula saya menduga batik motif khas Papua ini diproduksi di Papua, oleh orangorang asli Papua. Namun, saat saya berkunjung ke toko-toko batik di sejumlah kota di Papua, saya mempertanyakan kembali dugaan tersebut. Saya mengamati, setiap toko batik yang populer di sejumlah kota di Papua, bukan dimiliki oleh orang Papua.

Kenyataan tersebut mengingatkan saya pada obrolan sekitar tahun 2011 dengan warga setempat saat saya sedang dalam perjalanan dari Blitar ke Yogyakarta dalam sebuah angkutan umum. Teman sebangku, laki-laki sekitar usia 40an, bercerita tentang pekerjaannya sebagai pembuat motif kain batik. Ia banyak melakukan perjalanan, dari Sumatera hingga Papua. Ia banyak mengamati motif daun, bentuk-bentuk flora dan biota endemik. "Batik motif khas Papua itu salah satunya diproduksi di Pekalongan," cerita lakilaki itu.

Memang dalam empat tahun terakhir, saya mendengar bahwa ada orang Papua yang memproduksi batik di Kabupaten Jayapura. Meskipun demikian, beberapa teman penggemar batik yang tinggal di Jawa dan sering bepergian ke Jayapura sering kesulitan saat mencari batik di toko-toko yang dikelola oleh orang Papua. "Kadang tokonya tidak buka", kata teman itu. "Saat toko buka, kadang mereka tidak punya stok", tambah teman itu. Alasan yang sering diungkapkan pemilik toko adalah bahwa pemerintah tidak memberi dukungan pada usaha produksi batik orang lokal Papua. Sementara, pemilik toko berpendapat bahwa usaha mereka tidak akan dapat berkembang dengan maksimal apabila hanya menggantungkan keuntungan dari penjualan batik produksi mereka. 


\section{Referensi}

Jeacle, Inggrid, 2012, “Governing and Calculating Everyday Dress”, Foucault Studies, No.13:82-98.

Pademme, Arjuna. 2014. Kajati Papua Perintahkan Kejari Jayapura Tahan Tersangka Korupsi Batik, https://jubi.co.id/kajati-papua-perintahkan-kejari-jayapura-tahantersangka-korupsi-batik/ 